\title{
Preparasi Nanopartikel Senyawa Pentagamavunon-0 Menggunakan Matriks Polimer Kitosan Rantai Sedang dan Pengait Silang Natrium Tripolifosfat Melalui Mekanisme Gelasi Ionik Sebagai Kandidat Obat Antiinflamasi
}

\author{
Nanoparticle Preparation of Pentagamavunon-0 Using Medium Viscous \\ Chitosan Matrix Cross Linked by Sodium Tripolyphosphate Through Ionic \\ Gelation Mechanism as Anti-Inflammatory Candidate
}

\author{
Adhyatmika ${ }^{*}$, Ronny Martien ${ }^{1}$, Rochmadi' ${ }^{2}$, Hilda Ismail ${ }^{3}$ \\ 1. Departemen Farmasetika Fakultas Farmasi UGM \\ 2. Jurusan Teknik Kimia Fakultas Teknik UGM \\ 3. Departemen Kimia Farmasi Fakultas Farmasi UGM \\ Corresponding author: Adhyatmika: Email: adhyatmika@ugm.ac.id
}

\begin{abstract}
ABSTRAK
Pentagamavunon-0 (disingkat PGV-0), suatu senyawa turunan kurkumin dengan rumus molekul 2,5-bis(4'-hidroksi-3'-metoksibenzilidin) siklopentanon, telah terbukti memiliki aktivitas anti inflamasi tanpa menimbulkan efek ulcerogenik. Namun, pada penggunaan oral, bioavailabilitas PGV-0 rendah karena kelarutannya yang rendah. Salah satu strategi untuk meningkatkan kelarutan PGV-0 adalah menggunakan preparasi nanopartikel. Penelitian ini bertujuan untuk memformulasikan nanopartikel kitosan-PGV0 melalui mekanisme gelasi ionik menjadi nanopartikel, dengan pengait silang tripolifosfat. Nanopartikel PGV-0 yang dihasilkan selanjutnya dikarakterisasi ukuran partikel, morfologi partikel, potensial zeta, entrapment efficiency, serta stabilitasnya dalam cairan lambung dan usus buatan. Nanopartikel PGV-0 kemudian diuji aktivitas anti inflamasinya dengan metode penghambatan volume udem terinduksi karagenin, serta afinitas enzimatiknya terhadap siklooksigenase (COX) 1 dan 2. Nanopartikel kitosan-PGV0 diformulasikan dari kombinasi PGV-0 0,05 \%, kitosan rantai sedang 0,05\%, dan TPP $0,002 \%$. Nanopartikel berukuran 144,37 $\pm 17,41 \mathrm{~nm}$ dengan bentuk amorf. Jumlah PGV-0 yang terkompleks sebesar 99,40 $\pm 0,08 \%$ dengan zeta potensial $+3,8 \pm 0,27 \mathrm{mV}$. Studi stabilitas dalam cairan lambung dan usus buatan menunjukkan 99,64-99,74 \% (AGF) dan 99,54-99,69 \% (AIF) PGV-0 masih stabil dalam nanopartikel. Nanopartikel PGV-0 pada dosis $5 \mathrm{mg} / \mathrm{kgBB}$ menunjukkan daya anti inflamasi sebesar 35,47 \% dan memiliki afinitas enzimatik terhadap siklooksigenase, spesifik terhadap COX-2.
\end{abstract}

Kata kunci: nanopartikel, PGV-0, kitosan rantai sedang, TPP, anti inflamasi

\begin{abstract}
Pentagamavunon-0 (PGV-0, abbreviated), a curcumin analogue with chemical structure as 2,5-bis(4'-hydroxy-3'-methoxybenzilidin)cyclopentanone, has proven to have anti-inflammatory activity and non-ulcerogenic. However, orally PGV-0 has low bioavailability because of its low solubility. One of the strategy to improve PGV-0 solubility in order to increase bioavailability is using nanoparticle carrier. The aim of the study is to formulate chitosan-PGV-0 nanoparticles through ionic gelation mechanism cross-linked by tripolyphosphate. PGV-0 nanoparticle produced was then characterized for its particle size, morphology, zeta potential, entrapment efficiency, and stability against artificial
\end{abstract}


gastric and intestinal fluids (AGF and AIF). PGV-0 nanoparticle was tested for its antiinflammatory activity by carrageenan induced inflammatory method, and its enzymatic affinity against enzyme cyclooxygenase (COX)-1 and COX-2. Chitosan-PGV-0 nanoparticles were formulated in the combination of $0,05 \%$ PGV-0, $0,05 \%$ medium-viscous chitosan and $0,002 \%$ TPP. The nanoparticles were 144,37 $\pm 17,41 \mathrm{~nm}$ amorphous particles. Amount of PGV-0 entrapped was $99,40 \pm 0,08 \%$ with $+3,8 \pm 0,27 \mathrm{mV}$ in zeta potential. Stability study in AGF and AIF was shown that 99,64-99,74 \% (AGF) and 99,54-99,69 \% (AIF) of PGV-0 remains in nanoparticles. Chitosan-PGV-0 nanoparticles at $5 \mathrm{mg} / \mathrm{kg}$ body weight was obtain $35,47 \%$ anti-inflammatory activity and has found to have self-affinity against COX enzyme, relatively selective to COX-2.

Keywords: Extract, Z.zerumbet, larvisidal, Ae.aegypti, $\mathrm{LC}_{50}$

\section{PENDAHULUAN}

Inflamasi atau peradangan merupakan suatu respon umum sistem tubuh akibat terjadinya luka atau masuknya benda asing yang kemudian menimbulkan gejala-gejala panas, nyeri, kemerahan, pembengkakan, atau kelainan fungsi. Oleh karena itu, inflamasi dapat terjadi di berbagai bagian organ atau sistem organ, dan memiliki spektrum identifikasi yang luas serta berpotensi menjadi penyebab kejadian patologis lain jika tidak diatasi (Katzung et al., 1986). Saat ini terapi inflamasi yang umum digunakan pada kasus-kasus non-spesifik adalah menggunakan obat-obat antiinflamasi non-steroid (OAINS) yang memiliki efek samping ulcerogenik (Asosiasi Rheumatologi Australia, 2008). Sebagai alternatif yang lebih aman adalah kurkumin, dimana pada studi toksisitas kronis terhadap hewan uji tikus terbukti aman pada lambung (Chavalittumrong et al., 2002) karena selektif pada enzim COX2 (Jurenka et al., 2009). Permasalahannya adalah penggunaan kurkumin ini masih sangat terbatas karena bioavailabilitasnya yang sangat rendah di dalam darah, di samping karena adanya gugus metilen aktif yang menyebabkan kurkumin mudah terdekomposisi.

$$
\text { Dalam usaha meningkatkan }
$$
bioavailabilitas kurkumin ini, Tim Molekul
Nasional Fakultas Farmasi Universitas Gadjah Mada telah mensintesis berbagai senyawa analog baru. Salah satunya yang telah berhasil disintesis oleh Sardjiman (2000), 2,5 -bis (4' - hidroksi - 3' metoksibenzilidin) siklopentanon, suatu senyawa analog kurkumin yang secara trivial disebut pentagamavunon-0 (disingkat PGV-0) yang lebih stabil dari kurkumin karena hanya memiliki satu gugus karbonil. Pentagamavunon-0 telah dibuktikan memiliki aktivitas antiinflamasi pada uji pra-klinis secara in vivo pada tikus (Sardjiman, 2000). Untuk itu, PGV-0 sebagai senyawa analog kurkumin merupakan salah satu alternatif lain yang potensial.

Kekurangan dari senyawa PGV-0 yang utama adalah kelarutannya dalam air yang sangat rendah, sehingga berimbas pada absorpsi yang buruk (MOLNAS, 2001) jika digunakan secara oral. Uji farmakokinetika menunjukkan profil kadar PGV-0 dalam darah yang sangat eratik (naik-turun) (Kustaniah, 2001). Pentagamavunon-0 cepat hilang dari peredaran darah dan profil kadarnya mengalami fluktuasi pada pemberian oral (Amalia, 2001). Oleh karena itu, perlu dicarikan formulasi yang tepat untuk mengatasi masalah absorpsi tersebut.

Salah satu strategi potensial yang dapat diaplikasikan adalah dengan memformulasikannya dengan suatu 
polimer menjadi sediaan nanopartikel yang bersifat lebih mudah terdispersi stabil dalam air (Saha et al., 2010). Salah satu metode pembuatan nanopartikel adalah melalui mekanisme gelasi ionik yang distabilkan dengan suatu pengait silang (cross-linker, bahasa Inggris) (Martien et al., 2006). Gelasi ionik melibatkan interaksi suatu senyawa dengan polimer yang memiliki gugus-gugus dengan muatan yang berlawanan.

Pentagamavunon-0 yang bermuatan negatif dalam air karena adanya gugus karbonil dan hidroksil dapat mengadakan interaksi ionik dengan gugus-gugus bermuatan positif. Kitosan merupakan polimer kationik dengan adanya gugus amonium dari ikatan D-glukosamin dan $\mathrm{N}$ asetil-D-glukosamin yang berikatan $\beta(1,4)$ glikosidik, terionisasi positif di dalam asam. Polimer ini dapat mengadakan mekanisme gelasi ionik dengan PGV-0.

Sebagai penelitian pendahuluan, polimer kitosan dengan panjang rantai sedang menjadi pilihan normatif yang ideal untuk melihat karakter partikel yang dihasilkan. Sebagai stabilisator partikel yang terbentuk, digunakan pengait silang bermuatan negatif, dimana natrium tripolifosfat (TPP) merupakan senyawa yang saat ini telah banyak digunakan. Anion TPP yang memiliki muatan negatif lima akan mengait sisa gugus amonium dalam satu polimer yang tidak digunakan berinteraksi dengan PGV-0.

Sifat kitosan yang biokompatibel dan biodegradabel (Tiyaboonchai, 2003) menjadikannya menjadi pilihan yang baik dalam preparasi nanopartikel PGV-0, khususnya dalam formulasinya sebagai kandidat obat anti inflamasi yang aman. Oleh karena itu, perlu dilakukan penelitian preparasi, karakterisasi, hingga uji aktivitas sistem yang dihasilkan sebagai suatu kandidat obat anti inflamasi yang potensial. Pada akhirnya diharapkan akan diperoleh suatu alternatif baru dalam terapi inflamasi yang efektif dan aman.

\section{METODOLOGI} Alat

Alat-alat gelas dan alat ukur volume yang lazim digunakan, timbangan elektrik (Sartorius BP $310 \mathrm{P}$ ), tabung mikro 1,5 mL (Eppendorf) dan 2,0 $\mathrm{mL}$ (Axygen), membran pH-meter (Hanna HI 8314), pengaduk vortex (Maxi Mix I Type 16700), pengaduk pemanas dan batang pengaduk magnet (Stuart Heat-stir CB162), penguap putar dan penangas digital (Stuart RE300 dan RE300DB), fibrator ultrasonic (Transsonic T570 Elma), homogenizer Ultra-Turrax (Janke dan Kunkel - IkaWerk), spektrofotometer sinar tampak dan UV (Genesys 10 UV Scanning), mikroskop elektron transmisi (JEOL JEM 1400), analisator ukuran partikel dan potensial zeta (Nicomp PSS 380), ultrasentrifugator (Eppendorf 5804 R), Plethysmometer (UGO Basile), plat sumuran mikro (Nunclon 96-well plate), pembaca plat mikro (Biorad - model 680 S/N 18721), penangas putar (Orbit).

\section{Bahan}

Pentagamavunon-0, murni KLT (CRC Fakultas Farmasi UGM), kitosan rantai sedang, viskositas 200-800 cps (SigmaAldrich), natrium tripolifosfat teknis 85\% (Sigma-Aldrich), akuades, etanol teknis 96\%, aseton teknis (CV General Labora), asam asetat, natrium asetat, dan $\mathrm{NaOH}$ glasial (Merck), etil asetat p.a. (Merck), $\mathrm{HCl}$ dan garam-garam cairan lambung dan usus buatan (Merck), dimetil sulfoksida (DMSO) (Merck), kalium diklofenak (Cataflam), $\mathrm{NaCl}$ 0,9\% pro injeksi (Otsuka), Natrium karboksi metil selulosa (CMC-Na atau tilosa) (Merck), karagenin (Merck), Colorimetric COX (ovine) inhibitor screening assay kit (Cayman), tikus (Rattus norvegicus) putih betina galur wistar.

\section{Metode Penelitian Optimasi}

Sejumlah seri kadar larutan PGV-0 dalam pelarut organik dikombinasikan 
dengan sejumlah seri kadar larutan kitosan rantai sedang. Masing-masing kadar PGV-0 dicampurkan dengan seri kadar larutan kitosan rantai sedang (volume 1:1). Campuran di dalam tabung mikro kemudian dilakukan pencampuran menggunakan vortex mixer (Maxi Mix I) selama 20 detik. Selanjutnya ditambahkan sejumlah larutan natrium tripolifosfat hingga kadarnya dalam larutan sebesar $0,01 \%$ dan $0,001 \%$. Campuran ini divorteks kembali selama 20 detik. Pada tahap akhir tutup tabung dibuka dan masing-masing pelarut organik dibiarkan menguap selama semalam. Pengamatan fisik dispersi yang terbentuk dilakukan setelah volume sisa hanya menyisakan separuh dari volume campuran awal, dimana pelarut organik PGV-0 awal seluruhnya menguap dan tidak mempengaruhi polaritas sistem dispersi. Keadaan fisik sistem dispersi yang paling stabil (formula terpilih) selanjutnya dilakukan scaling up pada volume $30 \mathrm{~mL}$ dan $100 \mathrm{~mL}$. Formula terpilih ini dibuat dengan cara yang sama, pada wadah $30 \mathrm{~mL}$ dan 100 mL. Volume PGV-0 dan kitosan tetap 1:1. Pada tahap akhir, penguapan dilakukan dengan menuangkan campuran pada cawan petri, agar penguapan yang terjadi menjadi lebih cepat (kontak dengan udara luar lebih besar). Formula terpilih dari tahap ini kemudian diproduksi dalam skala $500 \mathrm{~mL}$.

\section{Evaluasi kecepatan pengenapan}

Berbagai kombinasi formula yang telah dilakukan optimasi formula sebelumnya dibuat lagi masing-masing dengan metode pembuatan yang sesuai pada volume $30 \mathrm{~mL}$. Dispersi yang terbentuk kemudian dimasukkan ke dalam tabung reaksi yang telah diberi skala ukuran panjang dengan menggunakan kertas millimeter blok. Selanjutnya semua dispersi dalam tabung reaksi didiamkan pada rak secara tegak, dan diamati kecepatan pengendapannya pada menit ke-5, 10, 20, 30, 45, 60, 90, 120, serta jam ke-24, 48, dan 72. Pengukuran dilakukan terhadap tinggi lapisan paling atas endapan.

\section{Produksi nanopartikel}

Dibuat masing-masing $500 \mathrm{~mL}$ larutan PGV-0 dalam pelarut organik terpilih dan kitosan rantai sedang dalam dapar asetat $0,1 \mathrm{M} \mathrm{pH} \mathrm{4,0}$ pada kadar yang dipilih dari hasil optimasi. Keduanya dicampurkan dalam gelas beaker ukuran satu liter dengan pengadukan menggunakan pengaduk magnetik (Stuart heat-stir CB162) pada skala tujuh tanpa pemanasan selama 20 menit. Selanjutnya ditambahkan TPP dengan kadar dalam campuran dari formula hasil optimasi, dan pengadukan dilanjutkan kembali selama 20 menit. Kemudian campuran yang dihasilkan diuapkan dengan menggunakan rotary evaporator (Stuart RE300) pada pemanasan penangas air (Stuart RE300DB) suhu $50^{\circ} \mathrm{C}$. Setelah volume mencapai setengah dari volume campuran semula (pelarut organik menguap seluruhnya), dispersi yang terbentuk diberi perlakuan ultrasonikasi (Transsonic T570 Elma) selama 75 menit. Untuk lebih menghaluskan ukuran partikel yang terdispersi, dilakukan homogenisasi menggunakan homogenizer ultra-turrax (Janke dan Kunkel - Ika Werk) selama 60 menit.

\section{Karakterisasi morfologi}

Untuk mengetahui morfologi nanopartikel kitosan-PGV-0 digunakan mikroskop elektron transmisi (JOEL JEM1400). Sampel nanopartikel ditetesi diatas copper grid kemudian dilapisi karbon dengan alat Auto Carbon Coated selama 5 detik setelah itu dikeringkan pada suhu ruang selama 24 jam. Setelah sampel nanopartikel kering dilapisi lagi dengan carbon seperti tersebut di atas lalu copper grid dimasukkan ke dalam holder dan sampel siap dianalisis dengan percepatan 
voltage $120 \mathrm{kV}$ dan magnifikasi 120.000.

\section{Entrapment efficiency}

Perhitungan PGV- 0 dalam sistem nanopartikel dilakukan dengan metode ekstraksi. Nanopartikel PGV-0 hasil preparasi dengan kitosan dilarutkan dalam akuades dan di-vorteks sampai terbentuk larutan nanopartikel yang terdispersi. PGV0 bebas yang tidak terenkapsulasi dalam dispersi nanopartikel diekstraksi dengan menggunakan etil asetat, dengan cara ditambahkan $10 \mathrm{~mL}$ etil asetat, lalu dikocok bolak-balik selama satu menit dan dipisahkan fase air dan $f$ ase etil asetat. PGV-0 yang tidak terenkapsulasi dari formulasi nanopartikel ditetapkan dengan menggunakan spektrofotometer dengan cara mengukur serapannya pada panjang gelombang $420 \mathrm{~nm}$ dan dibandingkan dengan kontrol.

\section{Ukuran partikel dan potensial zeta}

Untuk mengetahui ukuran sediaan nanopartikel dan potensial zeta dilakukan pengukuran ukuran dan distribusi nanopartikel menggunakan alat particle size analyzer (Nicomp PSS 380). Sebanyak 2 tetes sampel nanopartikel, masingmasing ditambahkan $5 \mathrm{~mL}$ akuades, dan dicampur dengan cara membolak-balik. Setelah itu diambil $3 \mathrm{~mL}$ dan dianalisis.

\section{Entrapment stability pada AGF dan AIF}

Formula nanopartikel PGV-0 diinkubasi dalam cairan lambung buatan (campuran $\mathrm{NaCl} 0,2 \%$ dan $\mathrm{HCl} 0,26 \%$ pada pH 1,2) dan cairan usus buatan (campuran $20 \mathrm{mM}$ bikarbonat, $139 \mathrm{mM}$ klorida, $5 \mathrm{mM}$ kalium, $140 \mathrm{mM}$ natrium, $4 \mathrm{mM}$ kalsium, dan $3 \mathrm{mM}$ magnesium pada $\mathrm{pH}$ 7,0), kemudian dimasukkan ke dalam alat shaker waterbath (Orbit), pada suhu $37^{\circ} \mathrm{C}$, dengan kecepatan pengadukan $100 \mathrm{rpm}$. Sampel diambil tiap jam selama 4 jam untuk pengujian dalam cairan lambung buatan dan 5 jam untuk pengujian dalam cairan usus buatan. Cuplikan sampel diambil sebanyak $4 \times 1,6 \mathrm{~mL}$ kemudian diendapkan dengan ultrasentrifugasi pada kecepatan $12.000 \mathrm{rpm}$, suhu $10^{\circ} \mathrm{C}$, selama 15 menit. PGV-0 bebas yang tidak terenkapsulasi berada dalam supernatan diekstraksi dengan menggunakan etil asetat, dengan cara ditambahkan 4 $\mathrm{ml}$ etil asetat, lalu dikocok dan dipisahkan fase air dan fase etil asetat. Fase etil asetat ditetapkan kandungan PGV-0-nya dengan menggunakan spektrofotometer dengan pada panjang gelombang $400 \mathrm{~nm}$.

\section{Uji penghambatan inflamasi}

Sebanyak 18 ekor tikus (Rattus norvegicus) putih betina galur wistar dibagi ke dalam enam kelompok, dengan masingmasing kelompok berjumlah tiga tikus, berdasar perhitungan jumlah sampel mengikuti rumus Federer (David dan Arkeman, 2008). Selanjutnya pada kaki belakang sebelah kanan tiap tikus diberi tanda batas di atas tumit, dan diukur volumenya menggunakan plethysmometer (UGO Basile). Kemudian kaki tersebut diinjeksi dengan karagenin 1,0\% intraplantar, dan langsung diukur kembali volumenya sebagai volume udem menit ke0 , dan dilanjutkan secara berkala pada menit ke-30, 60, 90, 120, 150, 180, 210 , dan 240. Data yang muncul pada layar dicatat dalam satuan $\mathrm{mL}$.

Afinitas enzimatik terhadap COX: Disiapkan sebuah plat mikro 96 sumuran (Nunclon 96-well plate). Masing-masing kelompok dibuat triplikasi. Pertama, untuk blanko reagen (kelompok B/W) berisi 160 $\mu \mathrm{L}$ dapar assay ditambah $10 \mu \mathrm{L}$ heme. Kelompok aktivitas 100\% enzim berisi 150 $\mu \mathrm{L}$ dapar assay, $10 \mu \mathrm{L}$ heme, dan10 $\mu \mathrm{L}$ masing - masing COX-1 atau COX-2. Pada kelompok perlakuan (inhibitor) berisi $150 \mu \mathrm{L}$ dapar assay, $10 \mu \mathrm{L}$ heme, dan $10 \mu \mathrm{L}$ masing masing COX-1 atau COX-2. Semua sumuran yang telah berisi semua komponen tersebut selanjutnya ditambahkan $10 \mu \mathrm{L}$ pelarut masing-masing 


\begin{tabular}{cl}
\hline Kelompok & Perlakuan \\
\hline 1 & Blanko CMC-Na 0,5\% \\
2 & Blanko matriks kitosan rantai sedang-TPP \\
3 & Kontrol positif kalium diklofenak dosis $2,25 \mathrm{mg} / \mathrm{kgBB}$ \\
4 & Kontrol pembanding PGV-0 dosis $20 \mathrm{mg} / \mathrm{kgBB}$ \\
5 & Kontrol pembanding PGV-0 dosis $5 \mathrm{mg} / \mathrm{kgBB}$ \\
6 & Perlakuan nanopartikel PGV-0 setara dosis $5 \mathrm{mg} / \mathrm{kgBB}$ \\
\hline
\end{tabular}

akuades HPLC grade, DMSO, dan dapar asetat $\mathrm{pH}$ 4,0 (untuk kelompok B/W dan aktivitas $100 \%$ ), atau $10 \mu \mathrm{L}$ obat masingmasing kontrol positif kalium diklofenak, kontrol pembanding PGV-0, dan perlakuan nanopartikel PGV-0 (kelompok inhibitor). Selanjutnya microplate digoyang pelan selama beberapa menit hingga komponenkomponen di dalam sumuran tercampur baik. Kemudian microplate ditutup dan diinkubasi selama 5 menit pada suhu ruang. Setelah inkubasi, pada masingmasing sumuran ditambahkan $20 \mu \mathrm{L}$ TMPD (substrat kolorimetrik, terdapat di dalam kit) dan $20 \mu \mathrm{L}$ asam arakhidonat. Plate digoyangkan beberapa menit hingga komponen di dalam sumuran tercampur homogen, dan kemudian diinkubasi tertutup pada suhu ruang selama 5 menit. Kemudian segera dilakukan pembacaan serapan menggunakan pembaca plat mikro (Biorad 680) pada panjang gelombang 595 nm.

\section{HASIL DAN PEMBAHASAN Optimasi}

Hasil optimasi tahap awal dari kombinasi kadar PGV-0 pada pelarut etanol dan aseton dengan kitosan rantai sedang menghasilkan enam formula yang stabil, yaitu pada kombinasi PGV-0:kitosan (\%) 0,025: 0,025, 0,05: 0,025, 0,01: 0,025, 0,025:0,05, 0,05:0,05, dan 0,01:0,05. Dapar asetat merupakan pelarut ionik yang jelas memiliki polaritas yang mutlak. Sedangkan pelarut organik merupakan pelarut non-polar. Ketika masing-masing komponen terlarut pada pelarutnya masing-masing, kelarutan itu akan terganggu dengan perubahan polaritas media di sekitarnya. Pada saat PGV-0 dan kitosan dicampurkan, maka akan terbentuk media dengan polaritas gabungan antara dapar dan pelarut organik. Dapar asetat dan aseton memiliki polaritas dengan margin yang lebih lebar dibandingkan dapar asetat dengan etanol. Akibatnya, pada saat pencampuran, perubahan polaritas dari polaritas pelarut asal menjadi polaritas gabungan akan menjadi lebih lunak pada pencampuran etanol dengan dapar asetat, dan bersifat lebih ekstrim pada pencampuran dapar asetat dengan aseton. Hasilnya, setelah pelarut organik diuapkan seluruhnya, pada formula yang mengandung aseton akan langsung mengendap karena perubahan polaritas yang lebih bermakna, sedangkan pada penggunaan etanol, hal ini lebih tidak terlihat.

Dari keenam formula yang menunjukkan kestabilan sistem dispersi, kemudian dilakukan pengukuran tinggi endapan relatif $\left(\mathrm{H}_{\mathrm{R}}\right)$. Nilai HR ditampilkan pada (Tabel Ia dan Tabel Ib), masingmasing untuk penggunaan TPP $0,02 \%$ dan $0,002 \%$.

Dari nilai tinggi endapan relatif (HR) pada tabel, kemudian dipilih dua formula dengan HR terbaik, yakni pada kombinasi PGV-0: kitosan (\%) 0,05:0,05, masingmasing pada TPP $0,02 \%$ dan $0,002 \%$ karena keduanya tidak berbeda secara signifikan $(p>0,05)$. Kedua formula ini kemudian dipilih untuk dilanjutkan pada karakterisasi tahap selanjutnya. 
Tabel Ia. Tinggi endapan relatif TPP 0,02\%

\begin{tabular}{ccc}
\hline \multirow{2}{*}{ Konsen-trasi PGV-0 } & \multicolumn{2}{c}{ Konsentrasi kitosan } \\
\cline { 2 - 3 } & $0,025 \%$ & $0,05 \%$ \\
$0,025 \%$ & 0,168 & 0,124 \\
$0,05 \%$ & 0,115 & 0,412 \\
$0,10 \%$ & 0,042 & 0,172 \\
\hline
\end{tabular}

Tabel Ib. Tinggi endapan relatif TPP 0,002\%

\begin{tabular}{ccc}
\hline \multirow{2}{*}{ Konsen-trasi PGV-0 } & \multicolumn{2}{c}{ Konsentrasi kitosan } \\
\cline { 2 - 3 } & $0,025 \%$ & $0,05 \%$ \\
\hline $0,025 \%$ & 0,061 & 0,096 \\
$0,05 \%$ & 0,078 & 0,414 \\
$0,10 \%$ & 0,018 & 0,185 \\
\hline
\end{tabular}

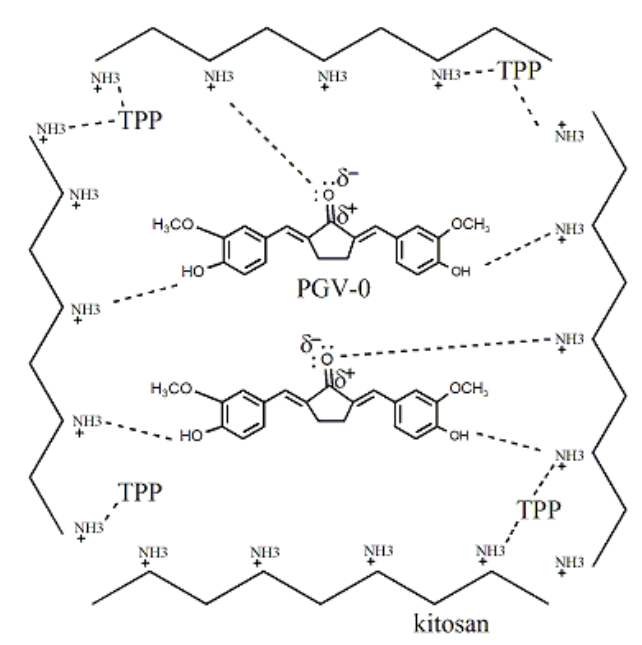

Gambar 1. Interaksi kimia yang terbentuk antara PGV-0, kitosan, dan TPP

\section{Produksi}

Produksi nanopartikel PGV-0 menggunakan matriks kitosan rantai sedang dan TPP menghasilkan dispersi yang lebih stabil dibandingkan dengan PGV-0 tanpa preparasi. Hasil produk nanopartikel (NCP-M) (Gambar 2), dibandingkan dengan PGV-0 tanpa preparasi (PGV-0). Produksi dilakukan pada skala $500 \mathrm{~mL}$ tiap batch.

\section{Karakterisasi ukuran partikel, indeks} polidispersitas, potensial zeta

Hasil analisis ukuran partikel nanopartikel PGV-0 dari formula terpilih yang merupakan keluaran dari analisator ukuran partikel
PSS380) (Tabel II). Pan et al., (2002) melaporkan bahwa nanopartikel kitosan dalam formulasinya untuk menghantarkan insulin secara per oral, pada ukuran ratarata sekitar $300 \mathrm{~nm}$ telah terbukti mampu secara efektif menurunkan gula darah tikus diabetes, dan peningkatan dosis mengakibatkan peningkatan penurunan gula darah tikus. Sejalan dengan itu, Fernandez-Urusunno et al., (1999) juga melaporkan bahwa hasil formulasi nanopartikel kitosan untuk insulin melalui gelasi ionik pada ukuran antara 300-400 $\mathrm{nm}$ dengan TPP sebagai stabilisator menghasilkan partikel bermuatan positif yang secara in vivo mampu menurunkan gula darah pada kelinci sebesar $40 \%$ 


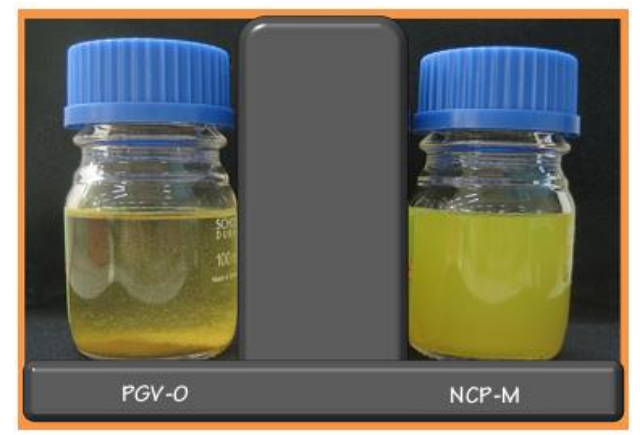

Gambar 2. Perbandingan produk NCP-M dengan PGV-0

Tabel II. Ukuran partikel, indeks polidispersitas, dan potensial zeta formula

\begin{tabular}{lccc}
\hline \multirow{2}{*}{ Formula } & \multicolumn{3}{c}{ Karakter keluaran dari PSA } \\
\cline { 2 - 4 } & Ukuran partikel (nm) & $\begin{array}{c}\text { Indeks } \\
\text { polidispersitas }\end{array}$ & Potensial zeta (mV) \\
\hline NCP-M 0,002T & $144,4 \pm 17,4$ & $0,41 \pm 0,03$ & $3,80 \pm 0,27$ \\
NCP-M 0,02T & $3.109,3 \pm 1.258,5$ & $16,97 \pm 3,53$ & $4,19 \pm 0,21$ \\
\hline
\end{tabular}

Tabel III. Nilai entrapment efficiency

\begin{tabular}{ccccc}
\hline Formula & Rep & EE (\%) & Rerata (\%) & CV (\%) \\
\hline \multirow{2}{*}{ NCP-M } & 1 & 99,37 & & \\
& 2 & 99,34 & 99,40 & 0,08 \\
& 3 & 99,49 & & \\
\hline
\end{tabular}

intranasal. Obat-obat yang lebih lipofil seperti siklosporin A yang diformulasi menggunakan nanopartikel kitosan pada ukuran sekitar $150 \mathrm{~nm}$ dan muatan +30 $\mathrm{mV}$ juga terbukti dapat mempertahankan konsentrasi plasma siklosporin A dalam darah pada $2,8 \mu \mathrm{g} / \mathrm{mL}$ selama tiga jam saat diadministrasikan per oral pada anjing (Bowman dan Leong, 2006). Oleh karena itu, ukuran nanopartikel PGV-0 ini telah cukup ideal untuk sistem penghantaran obat yang potensial, meskipun pembuktian yang pasti perlu dilakukan melalui pengujian aktivitasnya secara in vivo.

Selain data ukuran partikel, pada (Tabel II) juga dipaparkan data indeks polidispersitas (polydispersity index, PI), dimana pada NCP-M 0,002T, nilai PI tersebut sebesar 0,41 $\pm 0,03$. Indeks ini menggambarkan distribusi ukuran partikel dalam sistem dispersi, semakin kecil nilai indeks berarti ukuran partikel semakin homogen. Nilai ini menjadi penting karena jika rentang distribusi ukuran partikel luas, maka profil absorpsi secara keseluruhan menjadi sulits untuk dianalisis, karena karakter partikel yang sangat beragam. Selain itu, nilai indeks ini juga dapat digunakan untuk mengetahui seberapa jauh partikel telah teragregasi. Jika nilai ini terus berubah-ubah dari waktu ke waktu, maka hal ini menunjukkan proses agregasi telah terjadi. Jika digunakan batas variasi sebesar $10 \%$, maka nilai PI nanopartikel masih cukup besar, karena mencapai $41,1 \%$. Artinya, meski tetap pada rentang ukuran nano, nanopartikel PGV-0 dalam sistem masih kurang homogen. Hal ini disebabkan karena pada ukuran partikel yang semakin kecil, akan sangat sulit diperoleh variasi pada batas yang sama pada partikel makro, karena nilai variasi ini bersifat relatif terhadap rerata. Oleh karena itu, pada ukuran partikel sebesar $144,4 \pm 17,4 \mathrm{~nm}$, nilai PI sebesar 0,41 \pm 0,03 ini masih cukup baik dan dapat 


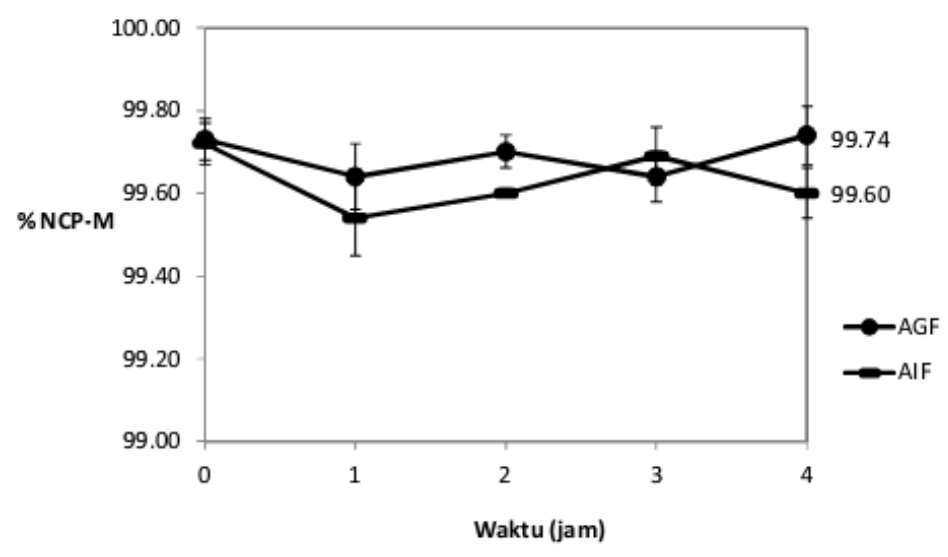

Grafik 1. Profil Entrapment stability

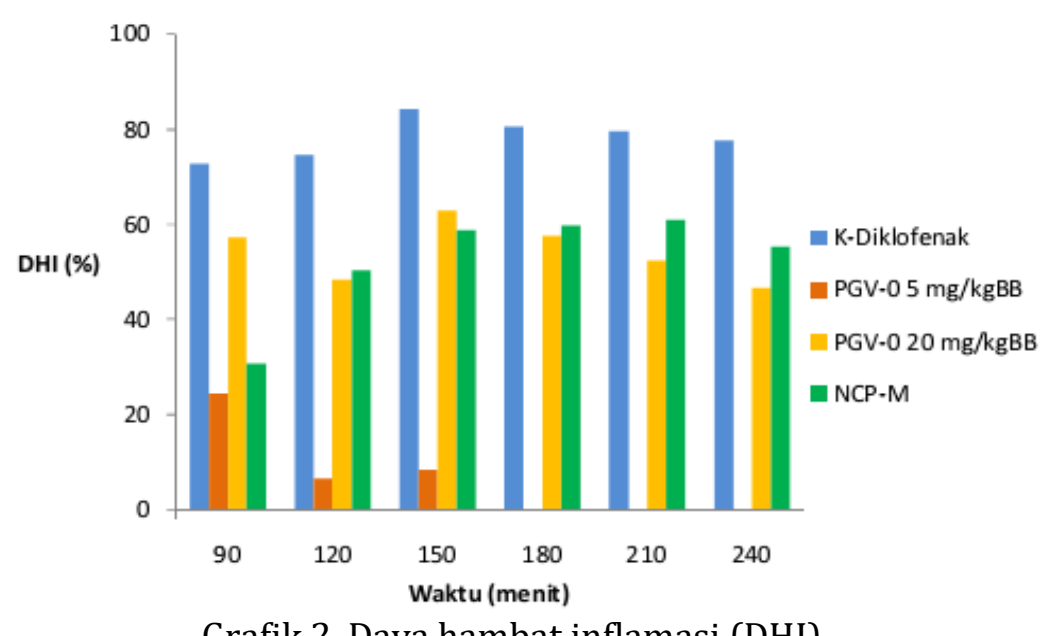

Grafik 2. Daya hambat inflamasi (DHI)

diterima. Dengan indeks ini, berarti ukuran partikel berkisar antara 85,03 hingga 203,71 nm. Pada ukuran partikel yang terdistribusi normal, nilai maksimum dan minimum ini jumlahnya sangat kecil.

Meskipun dalam formulasi akhirnya kebanyakan gugus amonium ini berikatan dengan PGV-0 dan TPP, namun karena kitosan merupakan polimer, gugus amonium yang dimilikinya tetap tersisa dan menyebabkan densitas muatan positif. Muatan positif ini bagus untuk penghantaran obat, didukung dengan nilai muatannya yang tidak terlalu besar, sehingga cukup aman bagi sel. Menurut Couvreur et al., (2002), muatan yang hanya sebesar $+3,80 \pm 0,27 \mathrm{mV}$ ini menyebabkan sistem nanopartikel menjadi kurang stabil, karena nilainya masih jauh di bawah $+30,0$ $\mathrm{mV}$. Gaya tolakan elektrostatis antar partikel tidak terlalu besar. Usaha peningkatan nilai potensial zeta dapat dilakukan dengan penambahan komposisi kitosan dalam campuran, namun hal ini berpotensi menyebabkan pembentukan partikel yang lebih besar. Oleh karena itu, nilai optimal potensial zeta untuk sistem dispersi secara umum adalah bersifat spesifik untuk tiap tujuan penghantaran obat. Nilai muatan yang pasti untuk nanopartikel sediaan obat secara umum tidak dapat dijustifikasi hanya dari sisi kestabilannya. Potensial zeta yang bernilai positif ini selanjutnya berperan dalam menjaga stabilitas nanopartikel PGV-0 dalam sistem dispersi, meski pada ukuran 


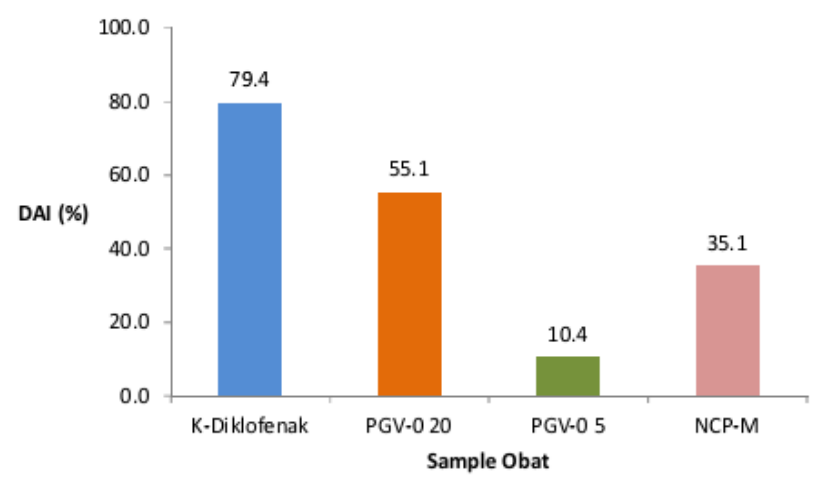

Grafik 3. Daya anti-inflamasi (DAI)

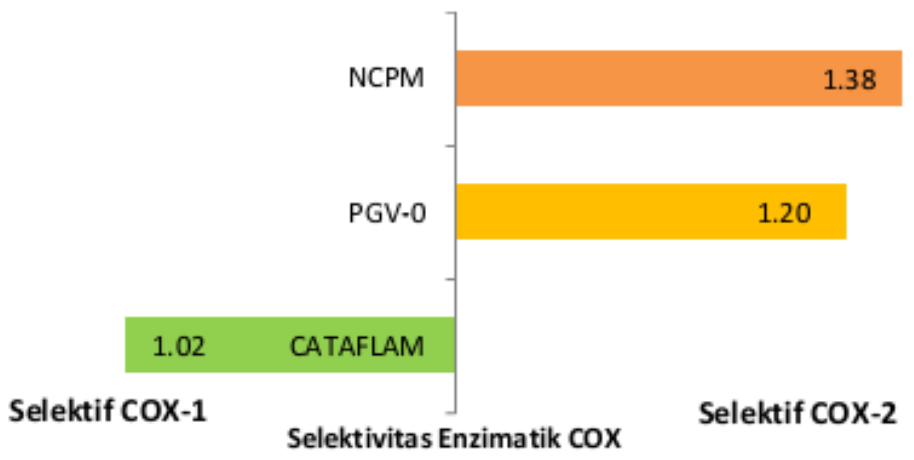

Grafik 4. Afinitas enzimatik terhadap COX

partikel mikro (lebih besar dari $1000 \mathrm{~nm}$ ). Hal ini tampak pada formula dengan penggunaan TPP pada kadar 0,02\%. Jika kita tilik dari awal proses optimasi formula, dapat dikatakan bahwa dari nilai $\mathrm{H}_{\mathrm{R}}$ formula ini stabil, sama dengan formula dengan penggunaan TPP $0,002 \%(\mathrm{p}>$ $0,05)$. Jika diasumsikan bahwa mikropartikel ini telah terbentuk sejak awal pembuatan, maka semestinya pengendapannya akan berlangsung jauh lebih cepat, namun hal ini tidak terjadi. Alasan utama dari terjadinya fenomena ini adalah karena gaya tolak menolak antar partikel yang timbul karena potensial zeta yang cukup besar untuk menjaga dispersi cukup stabil berada dalam kondisi terdispersi, yang akan dibahas selanjutnya pada pembahasan karakter potensial zeta.

\section{Entrapment efficiency}

Tabel III menunjukkan hasil analisis EE pada nanopartikel PGV-0. Nilai EE sebesar 99,40 \pm 0,08 \% menunjukkan metode pembuatan nanopartikel PGV-0 yang dilakukan sudah sangat efektif, sehingga mampu mengikat hampir keseluruhan PGV-0 yang diformulasikan ke dalam bentuk kompleks nanopartikel. Reaksi gelasi ionik secara umum memang dapat terjadi secara spontan dalam pencampuran yang homogen, sehingga memungkinkan untuk pengikatan zat aktif ke dalam matriks dengan efisien (Bisht et al., 2007; Kafshgari et al., 2011). Penambahan TPP sebagai pengait silang juga berperan dalam menjaga kestabilan nanopartikel, sehingga pada proses pemisahan PGV-0 bebas tidak terjadi kerusakan kompleks nanopartikel dalam waktu singkat selama proses analisis, yang dapat menurunkan EE.

\section{Entrapment stability pada AGF dan AIF}

Profil kestabilan nanopartikel dalam cairan lambung dan usus buatan (AGF dan 
AIF) (Grafik 1). Dari hasil analisis statistik diperoleh hasil bahwa kompleks nanopartikel dalam AGF maupun AIF tidak berbeda signifikan dengan EE. Dari sini dapat disimpulkan bahwa nanopartikel stabil di dalam AGF maupun AIF.

Kestabilan nanopartikel di dalam AGF dan AIF ini tidak terlepas dari kesetimbangan kompleks nanopartikel yang dibentuk oleh masingmasing komponennya. Pada saat suasana asam di dalam AGF, kecenderungan kitosan untuk melarut dan meninggalkan kompleks distabilkan oleh adanya TPP. Selanjutnya, pada suasana relatif basa, kitosan cenderung melemah muatan positifnyadan melemahkan ikatannya dengan PGV-0. Pada kondisi ini, TPP kembali berperan untuk tetap mengaitkan kitosan satu sama lain, sehingga meski ikatannya dengan PGV-0 melemah, tidak sampai menimbulkan kerusakan berarti pada nanopartikel yang telah terbentuk.

\section{Aktivitas penghambatan inflamasi}

Aktivitas penghambatan inflamasi nanopartikel PGV-0 dapat dilihat dari berbagai parameter yang dapat diperoleh dari analisis hasil pengujian menggunakan penghambatan radang terinduksi karagenin ini. Di antaranya adalah nilai daya hambat inflamasi (DHI) pada tiap waktu pengujian serta daya anti-inflamasi (DAI) (Grafik 2 dan 3). Dari kedua parameter tersebut, dapat disimpulkan bahwa pada dosis yang sama, nanopartikel berhasil meningkatkan nilai DHI secara signifikan $(p<0,05)$, dan setara dengan dosis PGV-0 tanpa preparasi hingga empat kalinya.

Keberhasilan preparasi nanopartikel menggunakan matriks kitosan-TPP untuk meningkatkan efektivitas PGV-0 dalam penghambatan inflamasi secara in vivo dapat disebabkan oleh beberapa faktor. Beberapa faktor ini merupakan aspekaspek komprehensif, mengingat studi in vivo merupakan studi hubungan antara perlakuan dan/atau dosis dengan efek yang timbul pada subjek uji. Karena itu, semua hal yang dapat dimodifikasi pada semua tahapan mulai dari memasukkan obat ke dalam saluran pencernaan, hingga obat mengalami proses absorpsi, distribusi, metabolisme, dan menimbulkan efek, dapat menjadi faktor yang berpengaruh.

Pertama, sediaan nanopartikel menggunakan kitosan ini mampu merusak protein yang mengikat celah antar sel (disebut tight junction atau t-junction) secara temporer/sementara (Bhardwaj dan Kumar, 2006), sehingga memungkinkan obat untuk masuk melintasi celah tersebut. Peruraian $t$ junction ini bersifat reversal/temporal (tidak permanen), karena hanya melibatkan mekanisme redistribusi protein claudin-4 (Cldn4) dari membran sel ke sitosol sehingga $t$-junction terbuka. Saat kitosan telah lewat, maka protein $\mathrm{Cldn} 4$ akan disintesis untuk memperbaiki $t$ junction (Yeh et al., 2011). Kedua, potensial zeta nanopartikel PGV-0 yang bermuatan positif $(+3,8 \mathrm{mV})$ memungkinkan interaksi ionik antara ion $\mathrm{NH}^{3+}$ dari kitosan dengan gugus asam sialat yang bermuatan negatif pada membran saluran cerna (Vllasaliu et al, 2010), sehingga partikel dapat tertahan lebih lama di dalam saluran usus, dan memberikan waktu yang lebih lama bagi obat untuk terabsorpsi. Selain itu, nanopartikel kitosan juga memiliki kemampuan penetrasi intraseluler yang baik (Chabib et al., 2011), sehingga memberikan alternatif absorpsi melalui mekanisme endositosis. Akhirnya, secara umum, nanopartikel PGV-0 ini dapat terabsorpsi menembus membran usus melalui dua jalur, baik paraseluler maupun transeluler. Sedangkan pada PGV-0 tanpa preparasi nanopartikel, hanya dapat terabsorpsi secara transeluler, dimana karena kelarutannya yang rendah (Hakim et al., 2006) menyebabkan proses difusi pasif ini menjadi kurang optimal dan berjalan lambat. Kemudian dari aspek 
metabolisme, nanopartikel PGV-0 memberikan perlindungan pada PGV-0 di dalam darah terhadap metabolisme lintas pertama (first pass effect) oleh enzimenzim sitokrom P450 dalam liver. Salah satu mekanisme kerja yang utama dari metabolisme oleh enzim ini adalah dengan mengenali senyawa-senyawa yang cenderung non-polar, untuk dikonjugasi menjadi senyawa baru yang lebih polar dan kemudian dapat dibuang melalui ginjal. Preparasi menjadi bentuk nanopartikel menyebabkan kompleks bersifat polar, sehingga dapat mengelabuhi sistem metabolisme ini, meskipun tidak dapat sepenuhnya terhindar karena liver memiliki fungsi deaminasi (menyingkirkan gugus nitrogen) dari amina (Waugh dan Grant, 2010), yang dalam hal ini akan mempengaruhi stabilitas kitosan yang kaya gugus. Setidaknya PGV-0 akan dibebaskan secara bertahap di dalam darah, karena pada dasarnya kemampuan metabolisme oleh enzim sitokrom P450 bersifat partisi, sehingga pada nanopartikel jumlah PGV-0 dalam darah menjadi lebih terkontrol dan stabil karena tidak langsung mengalami metabolisme secara bersamaan. Hal ini memberikan keuntungan efek yang relatif lebih lama. Nilai DHI dari waktu ke waktu membuktikan hal ini, dimana pada PGV-0 tanpa preparasi nanopartikel kemampuan untuk menghambat terjadinya inflamasi lebih cepat menurun, sedangkan pada nanopartikel PGV-0 kemampuan ini mampu terjaga lebih lama.

Kombinasi dari peningkatan absorpsi dan penghambatan proses metabolisme ini kemudian secara komprehensif akan meningkatkan ketersediaan hayati (bioavailabilitas) PGV-0 dalam darah. Ketersediaan hayati yang meningkat dan terjaga (stabil) akan menyebabkan kadar obat dapat melampaui kadar efektif minimum dalam waktu yang lebih panjang, atau dalam farmakokinetika disebut meningkatkan durasi terapi. Selain durasi yang meningkat, puncak kadar kurva ketersediaan hayati PGV-0 juga meningkat, sehingga dapat meningkatkan respon efek, dalam hal ini penghambatan volume udem sebagai manifestasi dari kejadian inflamasi dalam tubuh. Artinya, dapat disimpulkan bahwa peningkatan aktivitas in vivo secara signifikan ini merupakan salah satu parameter peningkatan absorpsi obat, karena secara langsung berhubungan dengan ketersediaan obat dalam darah untuk mencapai konsentrasi efektif (Bowman dan Leong, 2006).

\section{Afinitas enzimatik terhadap COX}

Profil afinitas enzimatik nanopartikel terhadap COX-1 dan COX-2 (Grafik 4). Dari grafik diperoleh data bahwa PGV-0 baik dalam bentuk asalnya maupun setelah dipreparasi menjadi nanopartikel, memiliki afinitas yang relatif lebih selektif terhadap COX-2 dibandingkan terhadap COX-1. Dari hasil ini diperoleh kesimpulan bahwa nanopartikel PGV-0 masih aman terhadap lambung, dan seperti halnya PGV-0 tidak menimbulkan efek samping ulcerogenik.

\section{KESIMPULAN}

Nanopartikel PGV-0 dengan matriks kitosan rantai sedang dan TPP merupakan kandidat agen anti-inflamasi yang potensial, ditandai dengan kemampuannya meningkatkan aktivitas anti-inflamasi secara in vivo, serta selektivitasnya pada COX-2 sehingga tidak menimbulkan efek samping ulcerogenik. Namun demikian, masih perlu adanya pengembangan penelitian lebih lanjut pada tahap penentuan nilai dosis efektifnya pada jumlah hewan uji per kelompok yang lebih besar (power lebih kuat). Selanjutnya, perlu dicarikan solusi untuk tahap liofilisasi nanopartikel sehingga memungkinkan diperoleh kadar yang lebih tinggi. Perlu juga dipertimbangkan penggunaan bahan baku lokal untuk mendapatkan sistem yang lebih murah 
sehingga lebih ekonomis jika diterapkan pada skala industri.

\section{UCAPAN TERIMA KASIH}

Ucapan terima kasih penulis ucapkan pada Biro Oktroi Rossenno (BOR dan Akademi Ilmu Pengetahuan Indonesia (AIPI) atas hibah yang diberikan untuk mendanai penelitian ini. Ucapan terima kasih juga kami ucapkan pada Laboratorium Biofarmasetika Fakultas Farmasi UGM dan Laboratorium Polimer Jurusan Teknik Kimia Fakultas Teknik UGM atas dukungan dan kerjasamanya dalam penelitian ini.

\section{DAFTAR PUSTAKA}

Asosiasi Rheumatologi Australia, 2008, Patient information on NSAIDs, Arthritis Australia.

Amalia E., 2001, Profil kadar senyawa 2,5bis-(4'-hidroksi-3'-metoksi

benzilidin) siklopentanon dalam darah setelah pemberian secara oral pada tikus jantan SD, Skripsi, Fakultas Farmasi UGM, Yogyakarta.

Bhardwaj V. dan Kumar MNVR., 2006, Polymeric nanoparticles for oral durg delivery on Nanoparticle technology for drug delivery: Drug and the pharmaceutical science, chapter IX, Taylor dan Francis Group, New York, pp. 231-262.

Bisht S., Feldmann, G., Soni, S., Ravi, R., Karikar, C., Maitra, A., dan Maitra, A., 2007, Polymeric NanoparticleEncapsulated Curcumin ("nanocurcumin"): a Novel Strategy for Human Cancer Therapy, $J$. Biomater. Sci. Polymer Edn, 18(2): 205-221.

Bowman K., Leong KW., 2006, Chitosan nanoparticles for oral drug and gene delivery, a Review, Int. J. Nanomedicine, 1(2): 117-128.

Chabib L., Banne Y., Martien R., Ismail H., 2011, Formulasi nanokurkumin dan uji cellular uptake pada sel kanker, laporan penelitian, Proyek I-MHERE Fakultas Biologi UGM.

Chavalittumrong P., Chivapat S., Rattanajarasroj S., Punyamong S., Chuthaputti A., Phisalaphong C., 2002, Chronics toxicity study of curcuminoids in rats, Songklanakarin J. Sci. Technol., 24(4): 633-647.

Couvreur, P., Barrat, G., Fattal, E., Legrand, P., Vauthier, C., 2002, Nanocapsule Technology: a Review, Crit. Rev. Ther. Drug Carrier Syst, 19: 99-134.

David, Arkeman H., 2008, Evaluation of the oral toxicity of formaldehyde in rats, Universa Medicina, 27(3): 106-112.

Fernandez-Urussumo R., Calvo P., Remunant-Lopez C., et al., 1999, Enhancement of nasal absorption of insulin using chitosan nanoparticles, Pharm. Res., 16: 1576-1581.

Hakim AR., Nugroho AE., Hakim L., 2006, Profil farmakokinetika Pentagamavunon $\quad-0 \quad$ setelah pemberian kalium pentagamavunonat -0 secara oral pada tikus, Indon. J. Pharm., 17(4): 204-211.

Jurenka J S., 2009, Anti-inflammatory properties of curcumin, a major constituent of Curcuma longa: A review of preclinical and clinical research, Alt. Med. Rev., 14(2): 141$153 /$

Kafshgari MH., Khorram M., Khodadoost M., Khavari S., 2011, Reinforcement of chitosan nanoparticles obtained by an ionic cross-linking process, Iran. Polymer J., 20(5): 445-456.

Katzung BG., 1986, Farmakologi Dasar dan Klinik, edisi 3, diterjemahkan oleh Binawati HK., Penerbit Buku Kedokteran EGC, Jakarta.

Kustaniah, 2001, Profil kadar senyawa 2,5bis- (4' - hidroksi - 3'- metoksi benzilidin) siklopentanon dalam darah setelah pemberian secara oral pada tikus betina SD, Skripsi, Fakultas Farmasi UGM, Yogyakarta. 
Martien R., Loretz B., Bernkop-Schnűrch A., 2006¹, Oral Gene Delivery: Design of polymeric carrier systems shielding toward intestinal enzymatic attack, Biopolymers, 83: 327-336.

MOLNAS, 2001, Laporan Penelitian Farmakokinetika PGV-0 setelah pemberian injeksi intravena, peroral, dan intraperitoneal pada Tikus Jantan dan Betina, Proyek MOLNAS 1, Kerjasama PT Indofarma, PT Kalbe Farma, dan Fakultas Farmasi UGM, Buku IV, Yogyakarta.

Pan Y., Li Y., Zhao H., Zheng J., Xu H., Wei G., Hao J., Cui F., 2002, Bio-adhesive polysaccharide in protein delivery system: chitosan nanoparticles improve the intestinal absorption of insulin in vivo, Int. J. Pharm., 249: 139-147.

Saha P., Goyal AK., Rath G., 2010, Formulation and evaluation of chitosan-based ampicillin trihydrate nanoparticles, Tropic. J. Pharmaceut. Res., 9(5): 483-488.

Sardjiman, 2000, Synthesis of new series of curcumin analogues, biological activities, and qualitative structureactivity relationships, dissertation, Universitas Gadjah Mada, Yogyakarta.

Tiyaboonchai W., 2003, Chitosan nanoparticles: A promising system for drug delivery, Naresuan Univ. J., 11(3): 51-66.

Vllasaliu D., Exposito-Harris R., Heras A., Casettari L., Garnett M., Illum L., dan Stolnik S., 2010, Tight junction modulation by chitosan nanoparticles: Comparison with chitosan solution, Int. J. of Pharm., 400(1-2): 183-193.

Waugh A., Grant A., 2010, Ross and Wilson Anatomy and Physiology in Health and Illness $10^{\text {th }}$ Ed., diadaptasi oleh Nurachmah E., Angriani R., Dasardasar Anatomi dan Fisiologi, Penerbit Salemba Medika, Jakarta.

Yeh TH., Hsu LW., Tseng MT., Lee PL., Sonjae K., Ho YC., dan Sung HW., 2011, Mechanism and consequence of chitosan-mediated reversible epithelial tight junction opening, Biomaterials, 36(26): 6164-73. 